\title{
Evaluation of two commercial multiplex PCR tests for the diagnosis of acute respiratory infections in hospitalized children
}

\section{Le Wang}

Children's Hospital of Hebei Province

\section{Shuo Yang}

Children's Hospital of Hebei Province

\section{Xiaotong Yan}

Children's Hospital of Hebei Province

\section{Teng Liu}

Children's hospital of hebei province

\section{Mengchuan Zhao}

Children's hospital of Hebei Province

Dianping You ( $\sim$ lele19870204@163.com )

Children's hospital of hebei province

\section{Guixia Li ( $\nabla$ hbetlgx@126.com )}

Children's hospital of Hebei province https://orcid.org/0000-0003-3948-7488

\section{Research article}

Keywords: MCA, CE, ARTI, Children

Posted Date: June 19th, 2020

DOl: https://doi.org/10.21203/rs.3.rs-36565/v1

License: (9) (i) This work is licensed under a Creative Commons Attribution 4.0 International License. Read Full License 


\section{Abstract \\ Background}

Acute respiratory tract infections (ARTI), including the common cold, pharyngitis, sinusitis, otitis media, tonsillitis, bronchiolitis and pneumonia are the most common diagnoses among pediatric patients and account for the majority of antibiotic prescriptions. A clear and rapid diagnosis is the key to preventing antibiotic abuse. Recently, based on different detection principles, many multi-target molecular analyses that can simultaneously detect dozens of pathogens have been developed, thereby greatly improving sensitivity and shortening turnaround time. In this work, we conducted a head-to-head comparative study between melting curve analysis (MCA) and capillary electrophoresis assay (CE) in the detection of nine respiratory pathogens in sputum samples collected from hospitalized ARTI childre.

\section{Methods}

Through MCA and CE analysis, nine common respiratory pathogens were tested on hospitalized children under the age of 13 who met the ARTI criteria.

\section{Results}

A total of 237 children with sputum specimens were tested. For all the targets combined, the positive detection rate of XYRes-MCA was significantly higher than ResP-CE (72.2\% vs. $63.7 \%, p=.002)$. Some pathogens were detected more often with MCA, such as parainfluenza virus, influenza $B$ and coronavirus, and some pathogens do the opposite, such as adenovirus and influenza A (all $p<.01$ ). Very good kappa values for most of pathogens were observed, except for Influenza B and coronavirus (both $\mathrm{K}=.39$ ).

\section{Conclusions}

Multiplex melting curve and capillary electrophoresis assays performed similarly for the detection of common respiratory pathogens in hospitalized children, except for Influenza B and coronavirus. Higher sensitivity was observed in the melting curve assay. By using this sensitive and rapid test, it may improv patient prognosis and antimicrobial management.

\section{Background}

Acute respiratory tract infections (ARTI) is acknowledged as one of the greatest threats to pediatric health $[1,2]$. Nearly 1.9 million children died from ARTI, most of them from developing country [3]. Accurate early etiologic diagnosis is crucial to the outcome of ARTI [4]. Multiplexed PCR methods enable highthroughput pathogen detection in a short time using limited amount of samples, and this detection strategy may have a significant impact on the management of infectious diseases [5-7]. Our previous 
research report pointed out that multiplex-PCR assays applied on an automated capillary electrophoresis system can simultaneously detect human rhinovirus (HRV), influenza A (FluA), FluA-H1N1, FluA-H3N2, influenza B (FluB), adenovirus (ADV), human Bocavirus (HBoV), human metapneumovirus (HMPV), parainfluenza virus (HPIV), human coronavirus (HCoV), respiratory syncytial virus (RSV), M. pneumoniae and Chlamydia, all in one reaction $[8,9]$. However, many clinical laboratories, especially lab in the primary care, are not equipped with such highly specialized laboratory equipment, which limits their widespread use in developing countries like China.

In this regard, melting curve analysis (MCA) was developed based on multicolor probe-based fluorescence. Tm is a highly reproducible physical parameter, combining it with fluorophore signature, MCA assay is feasible identifying certain pathogenic bacteria or viruses [10]. This simple measurement is performed in a closed tube, reducing the possibility of contamination. It takes about 50 minutes to complete, ensuring fast turn-around time. Recently, a new kit based on MCA analysis has been commercialized and can detect FluA, FluB, ADV, HBoV, HMPV, HPIV-1, HPIV-2, HPIV-3, HCoV-229E, HCoVOC43, RSV and M. pneumoniae. To our knowledge, no studies have been conducted to evaluate the clinical performance of this new method [11-13].

This study describes the first evaluation of the clinical performance of the XYres-MCA kit, compared against the ResP-CE method in a head-to-head manner using 237 sputum specimens from children with ARTI.

\section{Material And Methods}

\section{Ethics Statement}

All sputum samples were collected for their original testing purposes and provided to the study without any patient identity. All aspects of the study were conducted according to the Institutional Review Boards of Children's Hospital of Hebei Province.

\section{Study population and specimen collection}

Between April to September 2019, patients who had developed ARTI signs and symptoms were enrolled in this study. Patients were asked to cough, and the expectorated sputum was collected. If the child is too young to cough, a sterile negative pressure suction catheter can be used to obtain the oropharyngeal suction into a transport tube containing VTM (Hopebio Technologies, Qingdao, China). On the same day, the samples were stored at $4{ }^{\circ} \mathrm{C}$ for nucleic acid extraction. Before extraction, a pipette tip was used to gently mix the sputum and VTM to liquefy it.

\section{Nucleic acid extraction}

DNA/RNA extraction is performed on an automated workstation (Smart LabAssist-16/32, Health Gene Technologies, China) [14]. A total of $200 \mu \mathrm{L}$ of liquefied sputum was used for nucleic acid extraction and eluted in $30 \mu \mathrm{L}$, which was divided into two parts for ResP-CE and XYres-MCA analysis, respectively. 


\section{XYres-MCA and ResP-CE assays}

The XYres-MCA kit (Geneworks Biotechnology, JiangSu, China) was used for amplification and MCA analysis. Probes are labeled with FAM, ROX and Cy5. MCA was performed after PCR amplification; thus, each hybrid will show unique characteristics through the combination of Tm and its corresponding fluorescent probes. The RT-PCR was completed on a thermocycler (Veriti Thermal Cycler, Applied

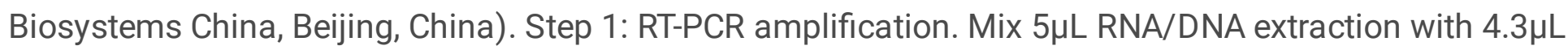
Res-reaction mixture 1 and $0.7 \mu \mathrm{L}$ Res-enzyme1. The thermal profile was $10 \mathrm{~min}$ at $25^{\circ} \mathrm{C} ; 30 \mathrm{~min}$ at $50^{\circ} \mathrm{C}$; 15 min at $95^{\circ} \mathrm{C} ; 40$ cycles of $30 \mathrm{~s}$ at $94^{\circ} \mathrm{C}, 30 \mathrm{~s}$ at $55^{\circ} \mathrm{C}, 30 \mathrm{~s}$ at $72{ }^{\circ} \mathrm{C} ; 10 \mathrm{~min}$ at $72{ }^{\circ} \mathrm{C}$. Step 2: PCR Amplification and MCA. $10 \mu \mathrm{L}$ of the RT-PCR product was mixed with $40 \mu \mathrm{L}$ PCR-MCA mixture, containing $39.8 \mu \mathrm{L}$ Res-reaction mixture 2 and $0.2 \mu \mathrm{L}$ Res-enzyme2. The thermal profile was 2 min at $95^{\circ} \mathrm{C} ; 10$ cycles of $15 \mathrm{~s}$ at $94^{\circ} \mathrm{C}, 15 \mathrm{~s}$ at $60^{\circ} \mathrm{C}, 15 \mathrm{~s}$ at $72{ }^{\circ} \mathrm{C} ; 30$ cycles of $15 \mathrm{~s}$ at $94^{\circ} \mathrm{C}, 15 \mathrm{~s}$ at $55^{\circ} \mathrm{C}, 15 \mathrm{~s}$ at $72{ }^{\circ} \mathrm{C}$; and then, the MCA began with denaturation for $2 \mathrm{~min}$ at $95^{\circ} \mathrm{C}$, hybridization for $90 \mathrm{~s}$ at $40{ }^{\circ} \mathrm{C}$, and a stepwise temperature increase $\left(1{ }^{\circ} \mathrm{C}\right.$ per $\left.20 \mathrm{~s}\right)$ from $40{ }^{\circ} \mathrm{C}$ to $90^{\circ} \mathrm{C}$. The levels of FAM, ROX, and Cy 5 fluorescence were collected and recorded during the MCA procedure.

ResP-CE analysis has been described in previous work, and we performed the experiments according to previously reported methods [14]. Table 1 illustrats the different detection targets of XYres-MCA and ResP-CE. 1) Targets not detected by the MCA assay include $\mathrm{H} 1$ and $\mathrm{H} 3$ influenza $A$, human rhinovirus and Chlamydia. 2) CE analysis can detect $1 / 2 / 3 / 4$ subtypes of parainfluenza virus but cannot distinguish them. MCA assay can detect and distinguish 1/2/3. 3) CE can detect 229E/OC43/HKU1/NL63 subtypes of human coronavirus but cannot distinguish them. MCA can detect and distinguish between 229E and OC43. 
Table 1

The spectrum of tested agents.

\begin{tabular}{|c|c|c|}
\hline & XYres-MCA & ResP-CE \\
\hline FluA & $\sqrt{ }$ & $\sqrt{ }$ \\
\hline FluA-H1N1 & & $\sqrt{ }$ \\
\hline FluA-H3N2 & & $\sqrt{ }$ \\
\hline FluB & $\sqrt{ }$ & $\sqrt{ }$ \\
\hline HPIV & $\sqrt{ }$ & $\sqrt{ }^{\mathrm{a}}$ \\
\hline HPIV1 & $\sqrt{ }$ & \\
\hline HPIV2 & $\sqrt{ }$ & \\
\hline HPIV3 & $\sqrt{ }$ & \\
\hline HMPV & $\sqrt{ }$ & $\sqrt{ }$ \\
\hline HBoV & $\sqrt{ }$ & $\sqrt{ }$ \\
\hline ADV & $\sqrt{ }$ & $\sqrt{ }$ \\
\hline $\mathrm{HCoV}$ & $\sqrt{ }$ & $\sqrt{ }^{b}$ \\
\hline HCoV-229E & $\sqrt{ }$ & \\
\hline HCoV-OC43 & $\sqrt{ }$ & \\
\hline RSV & $\sqrt{ }$ & $\sqrt{ }$ \\
\hline MP & $\sqrt{ }$ & $\sqrt{ }$ \\
\hline $\mathrm{Ch}$ & & $\sqrt{ }$ \\
\hline HRV & & $\sqrt{ }$ \\
\hline \multicolumn{3}{|c|}{$\begin{array}{l}\text { FluA, influenza A virus; FluB, Influenza B virus; HPIV, human parainfluenza virus; HMPV, human } \\
\text { metapneumovirus; HBoV, human bocavirus; ADV, adenovirus; HCoV, human coronavirus; RSV, } \\
\text { respiratory syncytial virus; MP, Mycoplasma pneumoniae; Ch, Chlamydia; HRV, human rhinovirus. }\end{array}$} \\
\hline${ }^{\mathrm{a}} \mathrm{HPIV}$ includ & & \\
\hline
\end{tabular}

\section{Statistical analyses}

The McNemar's test is used to compare the overall positive rate of pathogens between XYres-MCA and ResP-CE. The consistency between the two methods was evaluated using Kappa statistics ( $\mathrm{K}$ value $0.21-$ 
0.4 fair, $0.41-0.6$ moderate, $0.61-0.8$ substantial and $0.81-1$ almost perfect) [15]. Analysis was performed using SPSS version 19.0 (SPSS Inc., Chicago, USA). If $p<.05$, it is statistically significant.

\section{Results}

\section{Patient demographics and diagnosis}

A total of 237 patients were included in this study, and their sputum specimens were collected. The main diagnosis was pneumonia $(62.4 \%$, Table 2$)$. Participants were more likely to be male $(143 ; 60.3 \%)$ with a median age of 1.8 years (interquartile range $0.5-3.0$ years).

Table 2

Number of ARTI children enrolled by diagnosis.

\begin{tabular}{|llll|}
\hline Diagnosis & Number & Percentage \\
\hline Pneumonia & 148 & $62.4 \%$ \\
\hline Bronchitis/capillary bronchitis & 52 & $21.9 \%$ \\
\hline Common cold & 16 & $6.8 \%$ \\
\hline Otitis media & 12 & $5.1 \%$ \\
\hline Laryngitis/tonsillitis & 8 & $3.4 \%$ \\
\hline Pertussis syndrome & 1 & $0.4 \%$ \\
\hline
\end{tabular}

\section{Summary of XYres-MCA findings}

XYres-MCA detected one or more pathogens in 171 (72.1\%) of the 237 test samples (Table 3), with a total of 203 positive results (Table 4).

Table 3

Total number of XYres-MCA positive samples according to number of detected pathogens per sample.

\begin{tabular}{|lll|}
\hline Detected pathogens by XYres-MCA & Numbers of samples & \% of total samples $(\mathbf{n}=\mathbf{2 3 7})$ \\
\hline$>0$ & 171 & $72.1 \%$ \\
\hline 1 & 141 & $59.5 \%$ \\
\hline 2 & 28 & $11.8 \%$ \\
\hline 3 & 2 & $0.8 \%$ \\
\hline
\end{tabular}


Table 4

Number of XYres-MCA detected pathogens allocated by co-detection and age.

\begin{tabular}{|c|c|c|c|c|c|c|c|c|}
\hline Pathogen & $\begin{array}{l}\text { Total } \\
\text { number }\end{array}$ & $\begin{array}{l}\text { Detection in } \\
\text { co-infection }\end{array}$ & $\begin{array}{l}\text { Co- } \\
\text { detection } \\
\text { rate }(\%)\end{array}$ & $<$ year & $\begin{array}{l}1- \\
3 \text { years }\end{array}$ & $\begin{array}{l}3- \\
5 \text { years }\end{array}$ & $\overrightarrow{5}$ years & $P$ \\
\hline HPIV & 78 & 20 & 25.6 & 48 & 24 & 3 & 3 & 0.009 \\
\hline FluB & 42 & 6 & 14.3 & 11 & 17 & 7 & 7 & 0.003 \\
\hline$M P$ & 20 & 11 & 55.0 & 7 & 4 & 3 & 6 & 0.031 \\
\hline ADV & 11 & 6 & 54.5 & 8 & 2 & 0 & 1 & 0.279 \\
\hline RSV & 17 & 6 & 35.3 & 15 & 2 & 0 & 0 & 0.004 \\
\hline $\mathrm{HCoV}$ & 18 & 10 & 55.6 & 10 & 7 & 0 & 1 & 0.157 \\
\hline FluA & 9 & 3 & 33.3 & 4 & 2 & 2 & 1 & 0.778 \\
\hline HMPV & 6 & 1 & 16.7 & 4 & 1 & 1 & 0 & 0.597 \\
\hline HBoV & 2 & 0 & 0.0 & 1 & 1 & 0 & 0 & 0.780 \\
\hline Total & 203 & 63 & & 108 & 60 & 16 & 19 & \\
\hline
\end{tabular}

Multiple pathogens were detected in 17.5\% (30/171) of positive samples, and three types of pathogens (RSV/HPIV3/FluB, HPIV3/FluB/FluA) could be detected in one specimen. Most mixed infections contain two types of pathogens, which is the case in $28 / 30$ samples (93.3\%).

Table 4 shows the number of each pathogen detected by XYres-MCA according to co-infections, diagnosis and age. The most frequently detected pathogen was human parainfluenza virus, which was detected in 78 samples, of which 48 (61.5\%) were from infants under 1 year old. In addition, the positive detection rates of influenza B virus, RSV and $M$. pneumoniae were also related with age.

\section{Performance comparison of XYres-MCA and ResP-CE}

Overall, the positive detection rate of XYRes-MCA was significantly higher than ResP-CE $(72.2 \%$ vs. $63.7 \%$, Table 5, $p=.002$ ). 
Table 5

Total positive detection rates between XYres-MCA and ResP-CE analyses.

\begin{tabular}{|llll|}
\hline & & \multicolumn{2}{c|}{ No. (\%) of ResP-CE result } \\
\hline \multirow{2}{*}{ No. (\%) of XYres-MCA result } & & Positive & Negative \\
\cline { 2 - 4 } & Negative & $9(3.8)$ & $57(24.0)$ \\
\hline$P=0.002$ by McNemar's test. & & & \\
\hline
\end{tabular}

XYRes-MCA and ResP-CE agreed on the detection of 114 pathogens in the 237 samples (Table 6). Though either assay, at least one pathogen was detected in 124 cases (52.3\%): 101 with one pathogen and 13 with two or three pathogens. There were 57 (24.1\%) ARTIs with no pathogens detected by either assay. In consistent cases, HPIV was the most common single virus (16.9\%). Of the $66(27.8 \%)$ inconsistent cases, 7 (3\%) were completely inconsistent, and 59 (24.9\%) were partially inconsistent. Among the co-infected cases, most differences were MCA positive / CE negative (17.3\% vs $7.2 \%$ ) (Table 6). 
Table 6

Performance comparison between XYres-MCA and ResP-CE according to per sample.

\begin{tabular}{|llll|}
\hline Items & & Number & Percentage \\
\hline Concordant specimens & & 171 & $72.2 \%$ \\
\hline No pathogen detected & & 57 & $24.1 \%$ \\
\hline Single virus detected & HPIV & 101 & $42.6 \%$ \\
\hline & FluB & 40 & $16.9 \%$ \\
\hline & RSV & 29 & $12.2 \%$ \\
\hline & MP & 9 & $3.8 \%$ \\
\hline & FluA & 7 & $3.0 \%$ \\
\hline & ADV & 5 & $2.1 \%$ \\
\hline & HCoV & 5 & $2.1 \%$ \\
\hline & HBoV & 3 & $1.3 \%$ \\
\hline two or three pathogens detected & 2 & $0.8 \%$ \\
\hline Discordant specimens & & 1 & $0.4 \%$ \\
\hline completely inconsistent & & 13 & $5.5 \%$ \\
\hline partially consistent: more types of pathogens by MCA & 66 & $27.8 \%$ \\
\hline partially consistent: more types of pathogens by CE & 7 & $3.0 \%$ \\
\hline partially consistent: 1 pathogen inconsistent, others are consistent & 1 & $0.4 \%$ \\
\hline
\end{tabular}

The performance for individual targets is presented in Table 7. For most organisms, the agreement between XYRes-MCA and ResP-CE was excellent ( $\mathrm{k}>0.61)$. However, for certain organisms, including FluB and HCoV, XYRes-MCA results seem to be more sensitive than ResP-CE, as the positive detection rate of FluB was $100 \%$ vs. $88 \%$, HCoV was $95 \%$ vs. $32 \%$. 
Table 7

Detection sensitivity of XYres-MCA versus ResP-CE among individual targets.

\begin{tabular}{|llllll|}
\hline Pathogens & Positive cases & XYres-MCA (\%) & ResP-CE (\%) & kappa value & $P$ value \\
\hline HPIV & 81 & $78(96)$ & $64(79)$ & 0.800 & $<.001$ \\
\hline FluB & 42 & $42(100)$ & $37(88)$ & 0.394 & $<.001$ \\
\hline MP & 26 & $20(77)$ & $19(73)$ & 0.637 & $<.001$ \\
\hline ADV & 22 & $11(50)$ & $17(77)$ & 0.924 & $<.001$ \\
\hline RSV & 19 & $17(89)$ & $16(84)$ & 0.837 & $<.001$ \\
\hline HCoV & 19 & $18(95)$ & $6(32)$ & 0.394 & $<.001$ \\
\hline FluA & 12 & $9(75)$ & $11(92)$ & 0.791 & $<.001$ \\
\hline HMPV & 7 & $6(86)$ & $6(86)$ & 0.829 & $<.001$ \\
\hline HBoV & 2 & $2(100)$ & $1(50)$ & 0.665 & $<.001$ \\
\hline
\end{tabular}

\section{Discussion}

In China, the abuse of antibiotics is recognized as one of the greatest threats to human health, and it is also the major contributor to rising healthcare costs [16]. Due to the clinical similarity between bacterial and viral symptoms, rapid and comprehensive pathogen diagnostic tests should be used to prevent empirical or unnecessary antimicrobial treatment [17]. This study demonstrates for the first time the clinical performance of the new XYres-MCA analysis in detection of 12 types/subtypes respiratory pathogens. Compared with a CFDA approval multiplex-PCR assay, XYres-MCA can detect a higher percentage of positive results. Except for coronavirus and influenza $B$ virus, the two were very consistent for all pathogens ( $\mathrm{k}$ value $>0.61$ ),

An increasing number of recently published studies focus on the development of molecular methods to solve multiple detection in one reaction $[5,13,14,18,19]$. The multiplex-PCR methods has been previously evaluated versus conventional techniques $[1,6,8,20]$ or single-plex PCR [21]. Due to their advantages of automation, high repeatability, cost-effectiveness and high sensitivity, the use of multiplex PCR are recommended as first-line tests for detection of respiratory pathogens [7]. The comparative study is worthy of performed as the multiplex-PCR kits vary widely from a manufactory to another, on the scope of tested pathogens, detection principles and the equipment used [6, 22-24]. The CFDA has approved only one multiplex PCR kit, which requires highly specialized equipment worth millions of RMB, namely an automated capillary electrophoresis system, which exceeds the limit of purchasing equipment in most primary hospitals. MCA technology only requires a PCR instrument with four fluorescent channels. It is hoped that by comparative research data and low equipment price, it is possible to promote the application of multiple PCR technologies in primary hospitals. 
An important aspect of this study is the observation that a higher clinical sensitivity of the MCA in detecting viral infections in clinical samples than CE. The reason for the inconsistent results of influenza $B$ virus is unclear, but it may be explained by different target gene regions of the virus. In addition, the following two observations may explain why XYres-MCA showed advanced detection of parainfluenza virus and coronavirus, whereas a drop in sensitivity for the detection of Influenza A virus. First, when the test is applicable to the entire family or specific to a single type, the sensitivity may vary [25]. In this study, the subtypes of parainfluenza and coronavirus can be distinguished by XYres-MCA, while the subtypes of influenza A can be distinguished by ResP-CE. Second, 12 pathogens and one internal control (IC) were set in the same reaction in XYres-MCA, while CE detected 13 pathogens, one IC, one human DNA and one human RNA sequences. There are fewer targets in one reaction, resulting in less competition for primers, nucleotides or enzymes, which may lead to increased sensitivity [25, 26]. In addition, by using fluorophore and Tm value as dual labels, XYres-MCA has the following advantages: it can increases flexibility of probe design and can expand cross-platform compatibility, and if required, the assay can changed to accommodate more probes to detect new viruses or their subtypes.

In terms of co-detection, the core question is how to interpret it in a clinical sense. Though molecular methods, a positive result may indicate the true pathogen causing the disease or a harmless colonizer. It Is well known that most common respiratory pathogens can be existed in asymptomatic carriers [27], and high co-detection rates have been observed in our previous work and other studies using PCR methods $[18,28]$. In the routine clinical settings, children with mixed infections of two or more respiratory viruses are common due to the undeveloped immune system, but conventional methods are not easy to find. Whether the viral co-infection will cause the illness to become more serious is still controversial $[29,30]$. Therefore, results of additional detected viruses must be interpreted with caution, and their clinical relevance needs to be correlated in further studies.

\section{Limitations}

Our research has several limitations. First, due to budget restrictions, the study lasted 6 months. This may weaken the ability to capture epidemic pathogens during seasons. Second, as several pathogens (eg, Rhinovirus, Chlamydia) were not included in the target of XYres-MCA, so the performance of XYres-MCA assay to detect these pathogens cannot be determined. Third, compared to ResP-CE, the MCA panel does not contain a human DNA or RNA for monitoring the quality of respiratory specimens.

\section{Conclusions}

In conclusion, in this first clinical study of the new XYres-MCA analysis of 237 samples, we observed excellent sensitivity of this assay compared to another multiplex-PCR assay based on capillary electrophoresis. XYres-MCA analysis may be a new tool for respiratory virus testing in clinical laboratories and may have a positive impact on antimicrobial stewardship and isolation facilities. The flexibility of MCA technology in primer design and the characteristics that do not require highly specialized laboratory equipment are expected to play an active role in the emergence of new viruses. 


\section{Abbreviation}

HRV, human rhinovirus; RSV, respiratory syncytial virus; FluA, influenza A virus; HMPV, human metapneumovirus; HPIV, human parainfluenza virus; FluB, Influenza B virus; ADV, adenovirus; MP, Mycoplasma pneumoniae; $\mathrm{HCoV}$, human coronavirus; HBoV, human bocavirus; Ch, Chlamydia.

\section{Declarations}

\section{Funding}

This study was supported by the Finance Department of Hebei Province and Medical science research key project of Hebei province (20170402).

\section{Availability of data and materials}

The datasets generated and/or analyzed during the current study are available in the [Figshare] repository, [https://figshare.com/articles/MCAvsCE/12037701].

\section{Acknowledgments}

The study would not have been possible without the excellent support from clinical staff from the Respiratory Department at Children's Hospital of Hebei Province, and the laboratory staff from the Institute of Pediatric Research of Hebei.

\section{Authors' contributions}

LW and GXL designed the study and take responsibility for the entire process; LW conducted literature search, data extraction, quality assessment and draft writing; SY, XTY, TL and MCZ collected and analyzed the data, DPY edited the paper. All authors have read and approved the final paper.

\section{Ethics approval and consent to participate}

The study was approved by the Children's hospital Hebei Province Ethics Committee. Because there was no need to collect new specimens and the clinical data was de-identified, so the consent was waived by ethics committee of Children's Hospital of Hebei Province. After obtaining the permission, we can review patient records and use these data.

\section{Consent for publication}

Not applicable.

\section{Competing interests}

The authors declare that they have no competing interests. 


\section{References}

1. Collaborators GL. Estimates of the global, regional, and national morbidity, mortality, and aetiologies of lower respiratory tract infections in 195 countries: a systematic analysis for the Global Burden of Disease Study 2015. Lancet Infect Dis. 2017;17:1133-61.

2. Monto AS: Epidemiology of viral respiratory infections. Am J Med 2002, 112 Suppl 6A:4S-12S.

3. Williams BG, Gouws E, Boschi-Pinto C, Bryce J, Dye C. Estimates of world-wide distribution of child deaths from acute respiratory infections. Lancet Infect Dis. 2002;2:25-32.

4. Mahony JB. Detection of respiratory viruses by molecular methods. Clin Microbiol Rev. 2008;21:71647.

5. Tschiedel E, Goralski A, Steinmann J, Rath PM, Olivier M, Mellies U, Kottmann T, Stehling F. Multiplex PCR of bronchoalveolar lavage fluid in children enhances the rate of pathogen detection. BMC Pulm Med. 2019;19:132.

6. Pabbaraju K, Wong S, Tokaryk KL, Fonseca K, Drews SJ. Comparison of the Luminex xTAG respiratory viral panel with XTAG respiratory viral panel fast for diagnosis of respiratory virus infections. J Clin Microbiol. 2011;49:1738-44.

7. Schreckenberger PC, McAdam AJ. Point-Counterpoint: Large Multiplex PCR Panels Should Be FirstLine Tests for Detection of Respiratory and Intestinal Pathogens. J Clin Microbiol. 2015;53:3110-5.

8. Wang L, Zhao M, Shi Z, Feng Z, Guo W, Yang S, Liu L, Li G. A GeXP-Based Assay for Simultaneous Detection of Multiple Viruses in Hospitalized Children with Community Acquired Pneumonia. PLoS One. 2016;11:e0162411.

9. Wang L, Feng Z, Zhao M, Yang S, Yan X, Guo W, Shi Z, Li G. A comparison study between GeXPbased multiplex-PCR and serology assay for Mycoplasma pneumoniae detection in children with community acquired pneumonia. BMC Infect Dis. 2017;17:518.

10. Liao Y, Wang X, Sha C, Xia Z, Huang Q, Li Q. Combination of fluorescence color and melting temperature as a two-dimensional label for homogeneous multiplex PCR detection. Nucleic Acids Res. 2013;41:e76.

11. Kim SR, Ki CS, Lee NY. Rapid detection and identification of 12 respiratory viruses using a dual priming oligonucleotide system-based multiplex PCR assay. J Virol Methods. 2009;156:111-6.

12. Schouten JP, McElgunn CJ, Waaijer R, Zwijnenburg D, Diepvens F, Pals G. Relative quantification of 40 nucleic acid sequences by multiplex ligation-dependent probe amplification. Nucleic Acids Res. 2002;30:e57.

13. Liao S, Wang L, Ji X, Chen J, Li Q, Ma L. Simultaneous detection of 15 respiratory pathogens with a fluorescence probe melting curve analysis-based multiplex real-time PCR assay. Int J Mol Epidemiol Genet. 2019;10:29-37.

14. Wang L, Yang S, Yan X, Liu T, Feng Z, Li G. Comparing the yield of oropharyngeal swabs and sputum for detection of 11 common pathogens in hospitalized children with lower respiratory tract infection. Virol J. 2019;16:84. 
15. Landis JR, Koch GG. The measurement of observer agreement for categorical data. Biometrics. 1977;33:159-74.

16. Xiao Y, Zhang J, Zheng B, Zhao L, Li S, Li L. Changes in Chinese policies to promote the rational use of antibiotics. PLoS Med. 2013;10:e1001556.

17. Brendish NJ, Malachira AK, Armstrong L, Houghton R, Aitken S, Nyimbili E, Ewings S, Lillie PJ, Clark TW. Routine molecular point-of-care testing for respiratory viruses in adults presenting to hospital with acute respiratory illness (ResPOC): a pragmatic, open-label, randomised controlled trial. Lancet Respir Med. 2017;5:401-11.

18. Edouard S, Million M, Bachar D, Dubourg G, Michelle C, Ninove L, Charrel R, Raoult D. The nasopharyngeal microbiota in patients with viral respiratory tract infections is enriched in bacterial pathogens. Eur J Clin Microbiol Infect Dis. 2018;37:1725-33.

19. Parrott G, Kinjo T, Nabeya D, Uehara A, Nahar S, Miyagi K, Haranaga S, Tateyama M, Fujita J. Evaluation of Anyplex II RV16 and RB5 real-time RT-PCR compared to Seeplex((R)) RV15 OneStep ACE and PneumoBacter ACE for the simultaneous detection of upper respiratory pathogens. J Infect Chemother. 2017;23:859-61.

20. Arens MQ, Buller RS, Rankin A, Mason S, Whetsell A, Agapov E, Lee WM, Storch GA. Comparison of the Eragen Multi-Code Respiratory Virus Panel with conventional viral testing and real-time multiplex PCR assays for detection of respiratory viruses. J Clin Microbiol. 2010;48:2387-95.

21. Loens K, van Loon AM, Coenjaerts F, van Aarle Y, Goossens H, Wallace P, Claas EJ, leven M, Group GS. Performance of different mono- and multiplex nucleic acid amplification tests on a multipathogen external quality assessment panel. J Clin Microbiol. 2012;50:977-87.

22. Dabisch-Ruthe M, Vollmer T, Adams $\mathrm{O}$, Knabbe $\mathrm{C}$, Dreier J. Comparison of three multiplex PCR assays for the detection of respiratory viral infections: evaluation of XTAG respiratory virus panel fast assay, RespiFinder 19 assay and RespiFinder SMART 22 assay. BMC Infect Dis. 2012;12:163.

23. Bruijnesteijn van Coppenraet LE, Swanink CM, van Zwet AA, Nijhuis RH, Schirm J, Wallinga JA, Ruijs GJ. Comparison of two commercial molecular assays for simultaneous detection of respiratory viruses in clinical samples using two automatic electrophoresis detection systems. J Virol Methods. 2010;169:188-92.

24. Rand KH, Rampersaud H, Houck HJ. Comparison of two multiplex methods for detection of respiratory viruses: FilmArray RP and xTAG RVP. J Clin Microbiol. 2011;49:2449-53.

25. Pillet S, Lardeux M, Dina J, Grattard F, Verhoeven P, Le Goff J, Vabret A, Pozzetto B. Comparative evaluation of six commercialized multiplex PCR kits for the diagnosis of respiratory infections. PLoS One. 2013;8:e72174.

26. Xu Y, Yan H, Zhang Y, Jiang K, Lu Y, Ren Y, Wang H, Wang S, Xing W. A fully sealed plastic chip for multiplex PCR and its application in bacteria identification. Lab Chip. 2015;15:2826-34.

27. Walter JM, Wunderink RG. Severe Respiratory Viral Infections: New Evidence and Changing Paradigms. Infect Dis Clin North Am. 2017;31:455-74. 
28. Zhao MC, Wang L, Qiu FZ, Zhao L, Guo WW, Yang S, Feng ZS, Li GX. Impact and clinical profiles of Mycoplasma pneumoniae co-detection in childhood community-acquired pneumonia. BMC Infect Dis. 2019;19:835.

29. Scotta MC, Chakr VC, de Moura A, Becker RG, de Souza AP, Jones MH, Pinto LA, Sarria EE, Pitrez PM, Stein RT, Mattiello R. Respiratory viral coinfection and disease severity in children: A systematic review and meta-analysis. J Clin Virol. 2016;80:45-56.

30. Gonzalez AJ, Ijezie EC, Balemba OB, Miura TA. Attenuation of Influenza A Virus Disease Severity by Viral Coinfection in a Mouse Model. J Virol 2018, 92. 